\title{
PENGEMBANGAN AGROINDUSTRI TERINTEGRASI DI KAWASAN AGROWISATA BERBASIS NANAS DI KABUPATEN PEMALANG
}

\section{DEVELOPMENT OF INTEGRATED AGROINDUSTRY IN PINEAPPLE-BASED AGRITOURISM IN PEMALANG REGENCY}

\author{
Kartika Trianita, Anas Miftah Fauzi" ${ }^{*}$, dan Ade Iskandar \\ ${ }^{1}$ Program Studi Teknologi Industri Pertanian, Fakultas Teknologi Pertanian, Institut Pertanian Bogor \\ Kampus IPB Darmaga PO Box 220, Bogor 16002; \\ *Email korespondensi: amfauzi@apps.ipb.ac.id, fauzianas@yahoo.com
}

Makalah: Diterima 13 November 2019; Diperbaiki 23 April 2020; Disetujui 10 Mei 2020

\begin{abstract}
The development of integrated agroindustry in superior commodity-based agritourism becomes one of the programs to help to increase the villager's welfare. Complete and effective planning is needed to develop integrated agroindustry in agritourism with less risk of failure in implementation. The objective of this research was to develop an integrated agroindustry in pineapple-based agritourism in Pemalang Regency, including to determine the preferred agritourism facilities and pineapple-based products, and to determine the strategic location, and techno-economic analysis of pineapple-based factory. The respondent's preferences for agritourism facilities and pineapple-based products were collected by using a questionnaire. The strategic location was determined by using the Exponential Comparison Method. The feasibility of a pineapple-based factory consisted of the calculation of $N P V, I R R, N e t B / C, P B P$, and BEP. The results showed that the priority for procuring agrotourism facilities was the activity of pineapple processing tours, gazebos, children's playgrounds, cafeterias or eating places, photo spots, souvenir shops, pineapple field tours, and internet access. The more preferred products were fresh pineapple, pineapple pie, jelly, sweets, jam, chips, juice, nata de pina, candy, syrup, and stick. Belik District was chosen as the strategic location for agritourism based on pineapple. The pineapple-based factory was feasible for an establishment with investment cost of Rp12,287,857,290; working capital of Rp5,292,243,387; NPV of Rp18,506,493,138; IRR of 19.03\%; PBP of 4.26 year; Net B/C of 2.51; and BEPof $41.47 \%$.
\end{abstract}

Keywords: agritourism, agroindustry, honey pineapple, rural development

\section{ABSTRAK}

Pengembangan agroindustri terintegrasi di kawasan agrowisata berbasis komoditas unggulan dapat menjadi salah satu program untuk meningkatkan kesejahteraan masyarakat desa. Pengembangan agrowisata terintegrasi dengan agroindustri perlu direncanakan secara lengkap dan efektif untuk mengurangi risiko kegagalan dalam implementasi. Hasil penelitian ini berupa pengembangan agroindustri terintegrasi di kawasan agrowisata berbasis nanas di Kabupaten Pemalang, meliputi penentuan fasilitas agrowisata dan produk berbasis nanas, menentukan lokasi strategis kawasan agrowisata, dan menganalisis aspek tekno-ekonomi pabrik pengolahan nanas. Preferensi pengunjung/konsumen terhadap fasilitas agrowisata dan produk berbasis nanas dikumpulkan melalui kuesioner. Lokasi kawasan agrowisata terintegrasi dengan agroindustri nanas ditentukan dengan menggunakan Metode Perbandingan Eksponensial (MPE). Kelayakan pabrik pengolahan nanas dilihat dari nilai NPV, IRR, Net B/C, PBP, dan BEP. Hasil penelitian menunjukkan prioritas pengadaan fasilitas terdiri dari aktivitas kunjungan pabrik pengolahan nanas, tempat bersantai, tempat bermain anak, kafetaria atau tempat makan, tempat berfoto, toko cindera mata, susur kebun nanas, dan akses internet. Produk yang paling disukai konsumen terdiri dari buah segar, pai nanas, jeli, manisan, selai, keripik, jus/sari buah, nata de pina, permen, sirup, dan stik nanas. Kecamatan Belik terpilih sebagai lokasi kawasan agrowisata terintegrasi dengan agroindustri nanas. Pabrik pengolahan nanas layak didirikan dengan nilai investasi Rp12.287.857.290; modal kerja Rp 5.292.243.387; NPV Rp18.506.493.138; IRR 19,03\%; Net B/C 2,51; PBP 4,26 tahun; dan BEP 41,47\%.

Kata kunci: agroindustri, agrowisata, nanas madu, pengembangan desa

\section{PENDAHULUAN}

Banyaknya lapangan kerja di kota daripada di desa memberikan daya tarik bagi penduduk desa untuk melakukan urbanisasi demi memperbaiki kehidupan supaya menjadi lebih baik dengan cara yang lebih cepat. Hal ini menyebabkan terjadinya ketidakseimbangan ekonomi di desa dan kota karena kemiskinan masyarakat Indonesia masih terkonsentrasi pada wilayah pedesaan. Desa yang tidak berkembang, pada saatnya akan semakin tertinggal seiring dengan semakin berkembangnya zaman padahal pembangunan desa turut berperan dalam pembangunan nasional. Oleh karena itu, 
pembangunan desa perlu digalakkan untuk membantu pemerataan ekonomi dan mengurangi urbanisasi. Untuk membuka kesempatan kerja di suatu daerah, perlu mempertimbangkan sektor yang potensial dikembangkan. Sektor pertanian dan industri pengolahan termasuk sektor potensial di Kabupaten Pemalang (Suryani, 2013). Pengembangan agroindustri berfungsi meningkatkan perekonomian karena dapat mengatasi masalah rendahnya harga komoditas pada saat musim panen dan menyerap tenaga kerja.

Pengembangan agroindustri merupakan hal yang patut dipertimbangkan karena berpotensi meningkatkan cadangan devisa dan penyediaan lapangan pekerjaan. Pengembangan agroindustri akan sangat strategis jika dilakukan secara terpadu (saling terkait usaha sektor hulu hingga hilir) dan berkelanjutan (memanfaatkan teknologi konservasi sumberdaya dengan melibatkan kelompok/lembaga masyarakat, akademisi, dan pemerintah dalam semua aspek) (Djamhari, 2004). Agroindustri berkaitan langsung dengan sektor pertanian, sehingga pembangunan agroindustri penting dilakukan untuk mendukung pengembangan sektor pertanian. Kajian pengembangan agroindustri yang lengkap dan efektif sesuai dengan kebutuhan pasar perlu dilakukan sehingga diharapkan agroindustri ini dapat menjadi solusi terhadap permasalahan yang terjadi.

Kajian pengembangan agroindustri terhadap beberapa komoditas di Indonesia telah dilakukan sebelumnya. Supriatna et al. (2004) menganalisis sistem perencanaan model pengembangan agroindustri minyak daun cengkeh di Sulawesi Utara. Herman (2007) menganalisis model agroindustri bawang merah Brebes yang diolah menjadi serbuk bawang dan bawang goreng. Joen (2016) melakukan analisis potensi dan strategi penentuan kawasan agroindustri untuk dikembangkan di Kabupaten Lampung Selatan.

Kabupaten Pemalang adalah produsen nanas madu terbesar di Provinsi Jawa Tengah dengan jumlah produksi buah nanas sebesar 25.930 ton/tahun (BPS, 2018). Permintaan nanas saat ini terus meningkat. Namun, pada saat-saat tertentu, ada kalanya permintaan menurun sehingga terjadi kelebihan produksi nanas. Pada masa-masa tertentu, penjualan nanas menurun ketika musim penghujan dan panen raya komoditas buah lain, seperti mangga dan rambutan. Waktu turunnya permintaan di antara bulan Desember-Februari. Pada saat penjualan menurun, pendapatan petani atau pedagang turun sekitar 30\%. Mempertimbangkan hal tersebut, diperlukan alternatif produk olahan yang dapat diproduksi untuk menyerap kelebihan bahan baku tersebut. Perluasan atau penambahan industri olahan nanas dapat menjadi solusi untuk memberikan nilai tambah terhadap kelebihan produksi nanas serta mendukung pengembangan sektor pertanian dan industri pengolahan di Provinsi Jawa Tengah, khususnya Kabupaten Pemalang.
Selain memiliki komoditas unggulan, Kabupaten Pemalang juga memiliki banyak destinasi wisata yang berlokasi di wilayah pantai, tengah, maupun pegunungan. Bagian pegunungan Pemalang berada bagian selatan di kaki Gunung Slamet dengan kondisi sejuk. Destinasi wisata ini menyebar di banyak titik sehingga setiap kecamatan di Kabupaten Pemalang memiliki potensi wisata. Agrowisata dapat dikembangkan pada wilayah yang memproduksi komoditas unggulan. Wilayah yang memproduksi komoditas unggulan dan memiliki industri pengolahan dapat dikembangkan menjadi kawasan agrowisata yang terintegrasi dengan agroindustri berbasis komoditas unggulan. Mempertimbangkan potensi pengembangan nanas sebagai komoditas unggulan dan banyaknya destinasi wisata yang ada di Kabupaten Pemalang, program pengembangan agrowisata terintegrasi dengan agroindustri (ATA) berbasis nanas dapat menjadi alternatif solusi untuk membuka lapangan pekerjaan di desa.

Konsep ATA yg diusulkan adalah mengembangkan agroindustri nanas yang sudah ada dan mengembangkan potensi agrowisata nanas. Agroindustri yang berkembang dapat menghasilkan nilai tambah yang menjadi sumber pendapatan daerah. Adanya potensi agrowisata nanas juga bisa menjadi sumber penghasilan tambahan daerah. Integrasi dari keduanya dapat menjadi salah satu pilihan aktivitas yang dapat dilakukan di Pemalang sehingga menjadi salah satu program pengembangan daerah di Pemalang. Dalam hal ini, pengunjung dapat melakukan kunjungan agroindustri nanas sekaligus diedukasi mengenai proses yang terjadi di industri tersebut. Pengunjung dapat mengetahui bagaimana nilai tambah dapat tercipta dari adanya aktivitas industri pengolahan. Sinergi antara agrowisata dengan agroindustri ini diharapkan dapat menjadi sistem saling mendukung dalam meningkatkan nilai tambah keduanya.

Mengembangkan agroindustri di kawasan agrowisata dapat meningkatkan pendapatan para pelaku usaha sekaligus meningkatkan angka wisatawan yang datang ke Kabupaten Pemalang. Di samping itu, penelitian mengenai agrowisata yang dikaitkan dengan agroindustri masih belum banyak dilakukan. Djamudin et al. (2012) melakukan studi pengembangan agroindustri dan agrowisata terpadu di daerah aliran sungai Kali Bekasi Kabupaten Bogor dan menemukan bahwa proyek tersebut layak secara ekonomi untuk dijalankan. Fakhrurrazi (2018) melakukan analisis pengembangan agrowisata berbasis agroindustri kakao di Kabupaten Pidie Jaya Provinsi Aceh untuk mendorong daya saing dan pertumbuhan ekonomi lokal berbasis teknologi. Hasil penelitian menunjukkan bahwa pengembangan produk cokelat dapat menghasilkan nilai tambah. Rosyanta et al. (2018) merumuskan strategi pengembangan usaha agroindustri kopi luwak pada Satria Agrowisata di Kabupaten Gianyar. Hasil penelitian menunjukkan bahwa prioritas alternatif 
strategi adalah menjaga harga dan kualitas untuk ekspansi pemasaran.

Upaya pengembangan desa agrowisata melalui penguatan agroindustri terpadu produk unggulan daerah di Desa Temurejo Banyuwangi telah dilakukan oleh Ikasari et al. (2018). Upaya yang dilakukan berupa pembuatan SOP proses produksi, pengajuan nomor P-IRT, dan pembuatan desain kemasan yang lebih menarik dan informatif. Penelitian-penelitian sebelumnya menunjukkan bahwa industri pengolahan dapat menjadi solusi untuk peningkatan ekonomi dengan mempertimbangkan faktor harga, kualitas, dan pemasaran. Penelitian ini mengembangkan agroindustri dengan mempertimbangkan faktorfaktor tersebut melalui analisis tekno-ekonomi.

ATA yang dibangun tanpa perencanaan yang matang dapat mengurangi potensi keberhasilan saat implementasi. Oleh karena itu, pengembangan ATA perlu direncanakan secara lengkap dan efektif untuk mengurangi risiko kegagalan dalam implementasi. Pengembangan ATA perlu mempertimbangkan halhal yang dapat mendukung ATA tersebut menjadi program pembangunan daerah dengan memanfaatkan potensi pengembangan komoditas unggulan dan agrowisata yang ada. Penelitian ini ingin menunjukkan bahwa agrowisata dan agroindustri dapat dikembangkan dengan mempertimbangkan lokasi, jenis produk, dan aspek tekno-ekonomi. Pengembangan agrowisata dengan mempertimbangkan lokasi yang strategis dan penempatan fasilitas dapat mendukung keberlangsungan agrowisata sehingga dapat menjadi destinasi wisata yang menarik dan ramai dikunjungi orang. Pengembangan agroindustri berbasis nanas dengan mempertimbangkan produk yang sesuai preferensi pengunjung/konsumen dapat memberikan nilai tambah yang ditunjukkan dari hasil analisis tekno-ekonomi. Berdasarkan permasalahan yang perlu diselesaikan dalam pengembangan ATA, penelitian ini bertujuan untuk menentukan fasilitas agrowisata dan produk berbasis nanas sesuai dengan preferensi pengunjung/konsumen, menentukan lokasi strategis kawasan agrowisata berbasis nanas, dan analisis tekno-ekonomi pabrik pengolahan nanas.

\section{METODE PENELITIAN}

Penelitian ini dilakukan pada bulan November 2018 - Juni 2019 di Kabupaten Pemalang. Penelitian ini menggunakan pendekatan sistem dengan melakukan analisis deskriptif dan kuantitatif melalui studi kasus. Pengembangan agroindustri dilakukan di kawasan agrowisata sehingga fasilitas agrowisata harus mendukung dan memberikan kenyamanan pada wisatawan. Pengembangan agroindustri perlu mempertimbangkan produk yang fokus dikembangkan sehingga laku di pasaran. Kawasan agrowisata yang akan dijadikan pusat pengembangan agroindustri berbasis nanas perlu ditentukan sehingga dapat menjadi fokus program pengembangan daerah yang tepat. Agroindustri yang dikembangkan harus dapat memberikan keuntungan bagi pelaku usaha. Oleh karena itu, pada penelitian ini menggunakan parameter fasilitas agrowisata sesuai dengan preferensi pengunjung, produk berdasarkan preferensi konsumen, dan lokasi pusat agrowisata nanas dalam menentukan kelayakan pabrik pengolahan nanas meliputi analisis aspek teknologi dan finansial.

\section{Penentuan Fasilitas Agrowisata dan Produk Berbasis Nanas}

Fasilitas kawasan ATA dan produk berbasis nanas ditentukan berdasarkan preferensi pengunjung/konsumen. Daftar fasilitas kawasan agrowisata terintegrasi dengan agroindustri dan produk berbasis nanas ditentukan melalui studi literatur. Pengumpulan preferensi konsumen/ pengunjung diperoleh melalui kuesioner dengan Google Form yang disebar secara acak melalui media sosial. Pengisian Google Form dilakukan dengan mendata alamat email yang wajib diisi sehingga identitas responden dapat dilacak untuk menghindari terjadinya perhitungan data yang diisi oleh orang yang sama. Menurut Cohen et al. (2007), semakin besar jumlah sampel dari populasi akan menghasilkan data yang semakin baik. Namun, batas minimal yang harus diambil oleh peneliti adalah sebanyak 30 sampel. Penelitian ini, sebanyak 89 responden memberikan preferensinya terhadap fasilitas agrowisata dan produk berbasis nanas.

Responden memberikan penilaian berupa tingkat kepentingan terhadap diadakannya fasilitas kawasan dan tingkat kesukaan terhadap produk berbasis nanas. Fasilitas terpilih ditentukan menggunakan metode penambangan aturan asosiasi (Association Rule Mining - ARM). Metode ARM ini digunakan untuk mendapatkan aturan asosiasi dari data preferensi responden yang berjumlah besar sehingga diperoleh kombinasi fasilitas yang sesuai preferensi responden dalam menentukan perlu atau tidaknya untuk pengadaan suatu fasilitas kawasan ATA nanas. Fasilitas kawasan terpilih ditentukan dari aturan asosiasi yang menjadi prioritas. Penilaian dari responden diolah menggunakan perangkat lunak Waikato Environment for Knowledge Analysis (WEKA) 3.8 untuk menghasilkan prioritas aturan asosiasi.

Skala hedonik telah dicoba dan diuji dengan baik dalam riset konsumen untuk memperoleh data kesukaan (Stode dan Siddel, 1985). Dalam penelitian ini, tingkat kesukaan responden terhadap produk berbasis nanas menggunakan skala penilaian $1-9$ dengan tingkat kesukaan semakin tinggi pada nilai yang semakin besar. Preferensi responden terhadap produk berbasis nanas dinilai dengan memilih empat kategori, yaitu sangat suka, suka, tidak suka, dan sangat tidak suka yang memiliki skor secara berturutturut 9, 7, 3, dan 1. Empat kategori ini dipilih supaya 
responden dapat memberikan preferensi yang memiliki kecenderungan lebih kuat. Penilaian responden terhadap produk berbasis nanas dihitung menggunakan rata-rata geometri untuk memperoleh urutan preferensi produk.

\section{Penentuan Lokasi Strategis Kawasan ATA Nanas Dan Penempatan Fasilitas}

Lokasi strategis kawasan ATA berbasis nanas ditentukan dengan menggunakan Metode Perbandingan Eksponensial (MPE) dengan mempertimbangkan kriteria: nilai Location Quentiont (LQ), jarak lokasi dengan bahan baku, infrastruktur dan sarana transportasi, serta potensi wisata. Perhitungan dengan MPE merujuk pada Marimin dan Maghfiroh (2010).

Total nilai $\left(T N_{p}\right)=\sum_{q=1}^{m}\left(R K_{p q}\right)^{T K K_{q}}$

Keterangan:

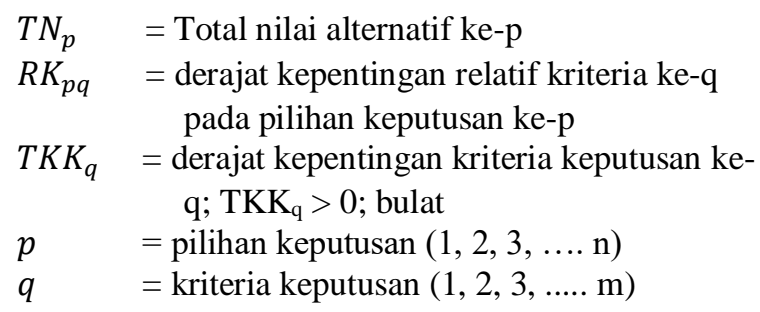

Pembobotan terhadap kriteria dan skor terhadap setiap alternatif dinilai oleh pakar yang berasal dari Bappeda (3 orang), Dispertan (1 orang), Diskoperindag (3 orang), dan Disparpora (1 orang). Total nilai MPE dari setiap alternatif merupakan jumlah dari nilai MPE dari setiap pakar.

\section{Analisis Tekno-Ekonomi Pabrik Pengolahan Nanas}

Analisis tekno-ekonomi adalah salah satu tahapan yang perlu dilakukan untuk memberikan gambaran pendirian agroindustri dan mengurangi ketidakpastian yang terjadi di masa depan. Analisis tekno-ekonomi meliputi analisis aspek teknis dan teknologi serta analisis finansial. Aspek teknik dan teknologi yang meliputi penentuan kapasitas produksi, pemilihan teknologi proses, mesin, dan alat, analisis pemanfaatan limbah atau produk samping, dan perhitungan neraca massa. Kapasitas produksi pabrik ditentukan dari jumlah produk yang dihasilkan dengan mempertimbangkan ketersediaan bahan baku. Pemilihan teknologi proses dilakukan berdasarkan ketepatan teknologi dengan bahan baku dan keberhasilan penerapan teknologi yang telah dilakukan sebelumnya (Kasmir dan Jakfar, 2004). Pemilihan mesin dan alat dilakukan berdasarkan kapasitas mesin dan alat yang dibutuhkan untuk proses produksi dengan teknologi yang ditentukan sebelumnya.

Analisis aspek finansial meliputi prakiraan kebutuhan dana dan analisis kelayakan investasi. Analisis finansial meliputi perhitungan Net Present Value (NPV), Internal Rate of Return (IRR), Net Benefit Cost Ratio (Net B/C), Break Even Point (BEP), dan Payback Period (PBP). Analisis finansial dilanjutkan dengan analisis sensitivitas untuk melihat pengaruh peningkatan harga bahan baku dan penurunan harga jual terhadap kelayakan usaha. Diagram alir kerangka penelitian ditunjukkan pada Gambar 1.

\section{HASIL DAN PEMBAHASAN}

\section{Penentuan Fasilitas Agrowisata Dan Produk Berbasis Nanas}

Hasil studi literatur diperoleh 12 fasilitas yang biasa terdapat di sebuah kawasan agrowisata, yaitu susur kebun, kunjungan pabrik pengolahan, penginapan, tempat berfoto, tempat bermain anak, tempat berkemah, jalur sepeda, akses internet, tempat bersantai, pertunjukan seni, toko cindera mata, dan kafetaria atau tempat makan. Data penilaian dari responden diolah menggunakan perangkat lunak WEKA 3.8 pada support count minimal $76 \%$ dan confidence lebih dari $90 \%$. Sepuluh aturan asosiasi pertama ditunjukkan pada Tabel 1. Fasilitas-fasilitas yang menyusun aturan asosiasi terdiri dari kunjungan pabrik pengolahan, tempat bersantai, tempat bermain anak, kafetaria atau tempat makan, tempat berfoto, toko cindera mata, susur kebun nanas, dan akses internet.

Berdasarkan produk yang sudah dikembangkan sebelumnya, dari studi literatur diperoleh 20 produk berbasis nanas untuk diberi penilaian oleh responden, yaitu buah segar, selai, kerupuk, keripik, dodol, acar, manisan, fruit leather, jus atau minuman sari buah, nata de pina, cuka, nanas kaleng, permen, sirup, pai, jeli, stik nanas, enzim bromelin, bioetanol, dan serat untuk tekstil. Hasil perhitungan rata-rata geometri penilaian terhadap produk berbasis nanas ditunjukkan pada Tabel 2 .

Dari hasil perhitungan diperoleh 11 produk berbasis nanas yang lebih disukai responden dengan nilai rata-rata geometri lebih dari 5, yaitu buah segar (8) diikuti dengan pai nanas (7), jeli (7), manisan (6), selai (6), keripik (6), jus/sari buah (6), nata de pina (6), permen (6), sirup (6), dan stik nanas (6). Buah segar menjadi produk nanas yang paling disukai ditunjukkan dari nilai rata-rata geometri paling tinggi. Hal ini dikarenakan buah segar merupakan produk yang masih alami, tidak melalui banyak proses dan penambahan zat aditif dan memberikan sensasi segar saat dikonsumsi. 


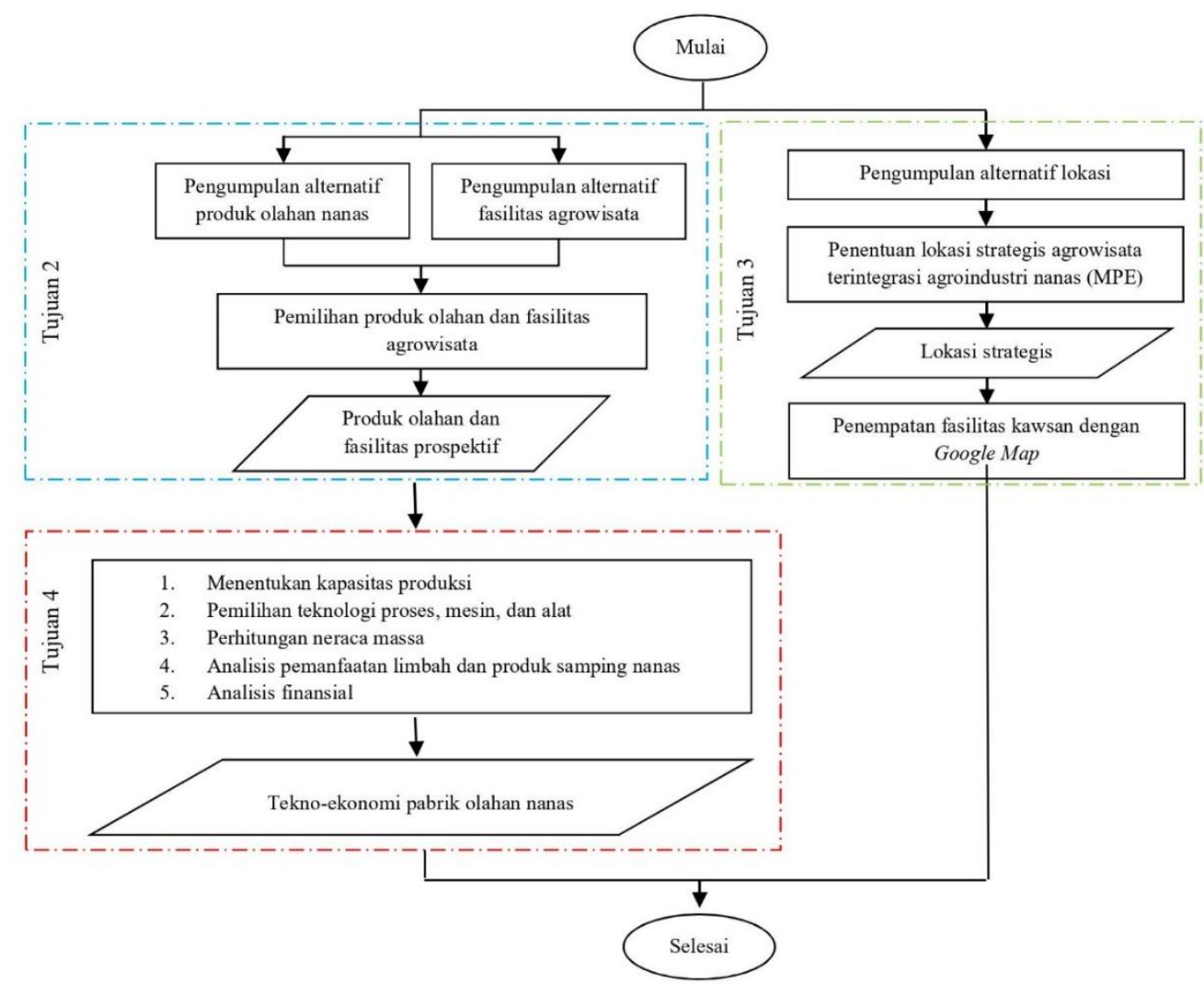

Gambar 1. Diagram alir kerangka penelitian

Tabel 1. Aturan asosiasi fasilitas agrowisata

\begin{tabular}{|c|c|c|c|}
\hline Antecedent & Consequent & $\begin{array}{l}\text { Support } \\
\text { count }\end{array}$ & Confidence \\
\hline Kunjungan pabrik pengolahan & Tempat bersantai & $80 \%$ & $100 \%$ \\
\hline Tempat bermain anak & Tempat bersantai & $78 \%$ & $100 \%$ \\
\hline Kafetaria & Tempat bersantai & $78 \%$ & $100 \%$ \\
\hline $\begin{array}{l}\text { Kunjungan pabrik pengolahan dan } \\
\text { tempat berfoto }\end{array}$ & Tempat bersantai & $78 \%$ & $100 \%$ \\
\hline $\begin{array}{l}\text { Kunjungan pabrik pengolahan dan } \\
\text { tempat bermain anak }\end{array}$ & Tempat bersantai & $77 \%$ & $100 \%$ \\
\hline $\begin{array}{l}\text { Kunjungan pabrik pengolahan dan } \\
\text { toko cindera mata }\end{array}$ & Tempat bersantai & $77 \%$ & $100 \%$ \\
\hline $\begin{array}{l}\text { Kunjungan pabrik pengolahan dan } \\
\text { kafetaria }\end{array}$ & Tempat bersantai & $77 \%$ & $100 \%$ \\
\hline Susur kebun nanas & $\begin{array}{l}\text { Kunjungan pabrik } \\
\text { pengolahan }\end{array}$ & $76 \%$ & $100 \%$ \\
\hline Susur kebun nanas & Tempat bersantai & $76 \%$ & $100 \%$ \\
\hline Akses internet & $\begin{array}{l}\text { Kunjungan pabrik } \\
\text { pengolahan }\end{array}$ & $76 \%$ & $100 \%$ \\
\hline
\end{tabular}


Tabel 2. Hasil perhitungan rata-rata geometri produk berbasis nanas

\begin{tabular}{lclc}
\hline Produk & Nilai rata-rata geometri & Produk & Nilai rata-rata geometri \\
\hline Buah segar & 8 & Stik nanas & 6 \\
Pai nanas & 7 & Kerupuk & 5 \\
Jeli & 7 & Dodol & 5 \\
Manisan & 6 & Acar & 5 \\
Selai & 6 & Fruit leather & 5 \\
Keripik & 6 & Nanas kaleng & 5 \\
Jus/sari buah & 6 & Serat nanas & 5 \\
Nata de pina & 6 & Bioetanol & 5 \\
Permen & 6 & Cuka & 4 \\
Sirup & 6 & Bromelin & 4 \\
\hline
\end{tabular}

$\mathrm{n}=89$ responden

\section{Penentuan Lokasi Strategis Kawasan Agrowisata Berbasis Nanas}

Alternatif lokasi yang dipilih untuk penentuan lokasi kawasan agrowisata berbasis nanas di Kabupaten Pemalang adalah Kecamatan Belik, Kecamatan Pulosari, Kecamatan Randudongkal, dan Kecamatan Pemalang. Kecamatan Belik, Pulosari, dan Randudongkal dipilih karena kecamatan tersebut memproduksi nanas. Kecamatan Pemalang tidak memproduksi nanas, namun dipilih karena merupakan pusat kota di Kabupaten Pemalang. Kriteria penentuan lokasi terdiri dari nilai LQ, jarak lokasi dengan bahan baku, infrastruktur dan sarana transportasi, dan potensi wisata.

Perbandingan total nilai MPE untuk setiap alternatif ditunjukkan pada Gambar 2. Hasil perhitungan dengan metode MPE menunjukkan nilai MPE tertinggi untuk Kecamatan Belik $\left(1,25 \times 10^{9}\right)$ diikuti oleh Pemalang $\left(4,20 \times 10^{8}\right)$, Randudongkal $\left(2,94 \times 10^{8}\right)$, dan Pulosari $\left(7,58 \times 10^{7}\right)$. Hasil penilaian pakar ini menunjukkan bahwa pakar memprioritaskan untuk lokasi strategis kawasan berada dekat dengan sumber bahan baku kemudian berada pada pusat kota.

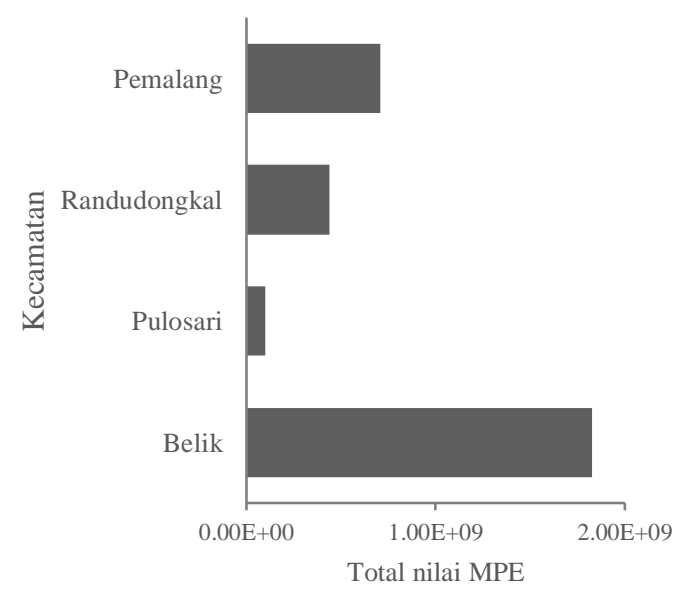

Gambar 2. Perbandingan total nilai MPE lokasi agrowisata terintegrasi dengan agroindustri
Kecamatan Belik yang terpilih sebagai kawasan agrowisata nanas di Kabupaten Pemalang telah memiliki beberapa fasilitas penting dalam sebuah kawasan agrowisata. Fasilitas yang sudah ada terdiri dari UMKM, wisata alam Telaga Silating dan Curug Bengkawah, serta restoran, kolam renang, hotel, dan tempat berfoto Jambe Kembar.

Penempatan fasilitas agrowisata berbasis nanas di Kabupaten Pemalang digambarkan dengan bantuan Google Map seperti ditunjukkan pada Gambar 3. Penggambaran ini memperlihatkan posisi dari setiap fasilitas-fasilitas yang sudah ada sehingga atraksi atau destinasi wisata tambahan dilokasikan pada posisi yang strategis dengan mempertimbangkan posisi fasilitas-fasilitas yang sudah ada.

Kawasan agrowisata terpilih adalah Kecamatan Belik dimana lokasi tersebut juga merupakan pusat produksi nanas. Penempatan fasilitas-fasilitas kawasan dimulai dari fasilitas yang sudah eksis. Pada peta dapat dilihat bahwa terdapat fasilitas yang berada di klaster biru dan klaster merah. Klaster biru terdiri dari Curug Bengkawah dan Telaga Silating sebagai objek wisata dan Vitanas sebagai UMKM dan toko cindera mata. Vitanas memiliki lokasi yang strategis di pinggir Jalan RandudongkalBelik. Klaster merah merupakan titik pusat aktivitas kawasan agrowisata karena pada klaster tersebut didominasi oleh fasilitas-fasilitas agrowisata nanas.

Pada klaster merah, terdapat Cita Rasa dan Nanas Madu Jaya selaku UMKM dan Jambe Kembar sebagai penyedia penginapan, tempat bermain anak, tempat berfoto, tempat makan, dan akses internet. Fasilitas tempat bermain anak dapat diwakili oleh kolam renang Jambe Kembar yang berupa water boom untuk anak. Fasilitas tempat berfoto diwakili oleh taman bunga Jambe Kembar yang dibentuk menjadi kawasan dengan pemandangan yang sangat indah dan cocok untuk berfoto. Akses internet terdapat di restoran Jambe Kembar. 


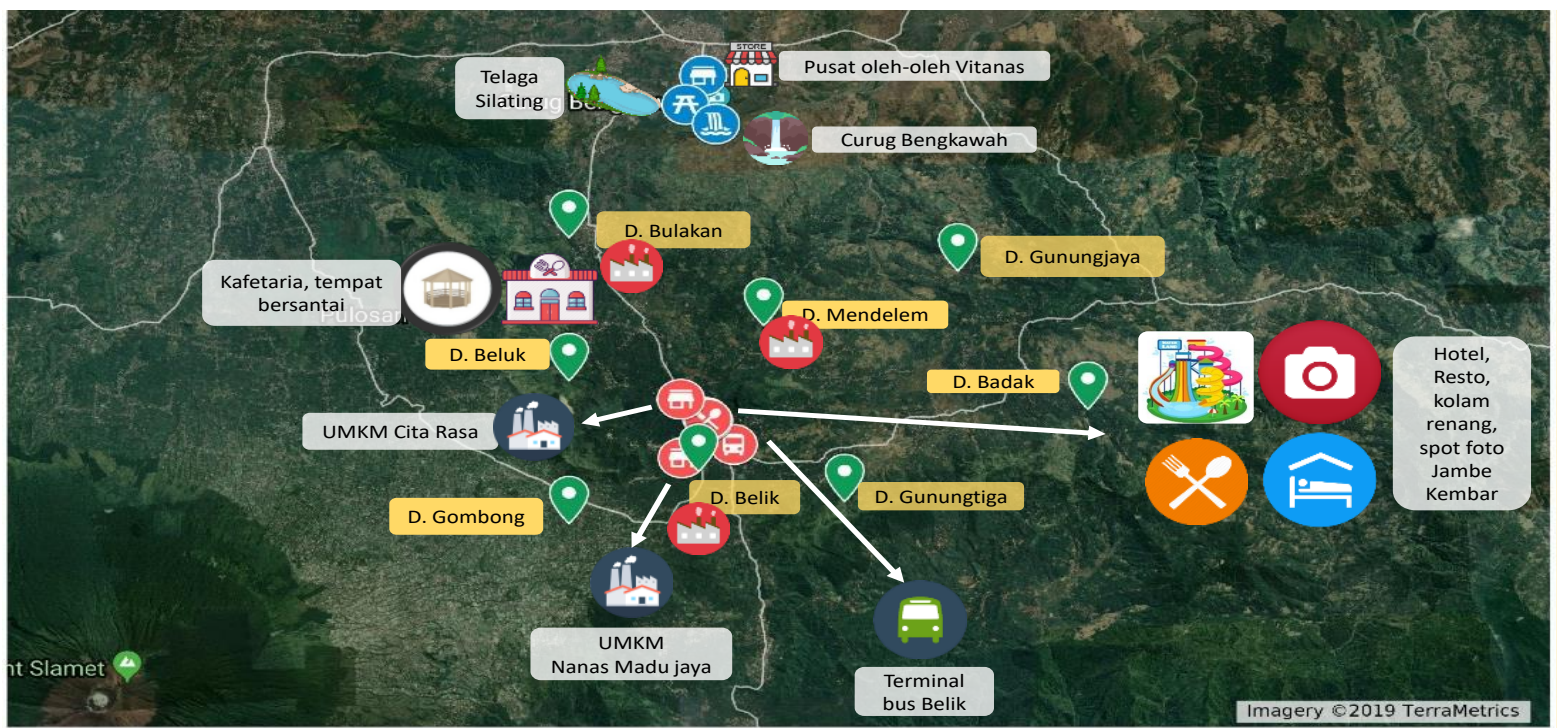

Gambar 3, Penempatan fasilitas kawasan ATA berbasis nanas (diakses pada 13 Nov 2019)

Fasilitas tempat bersantai (gazebo) juga dimiliki oleh Jambe Kembar yang berada di pinggir jalan dekat dengan restoran. Adanya fasilitas terminal bus. menunjukkan bahwa akses transportasi umum sudah menjangkau kawasan ini.

Titik-titik yang berwarna hijau menunjukkan desa-desa di Kecamatan Belik yang memproduksi nanas. Fasilitas tambahan kawasan berupa susur kebun nanas dapat ditempatkan pada salah satu atau beberapa desa yang memproduksi nanas tersebut. Menurut laporan dari Bappeda Pemalang (2016), Desa Beluk telah menggunakan $100 \%$ potensi lahan tanamnya untuk menanam nanas. Alternatif lokasi pabrik pengolahan nanas yang diusulkan adalah Desa Belik, Bulakan, dan Mendelem. Hal ini mempertimbangkan produksi nanas di desa-desa tersebut telah mencapai minimal 100 hektar dan persentase lahan yang sudah ditanam masih kurang dari $70 \%$ sehingga sisa lahan dapat dipertimbangkan untuk pembangunan pabrik yang dekat dengan produksi bahan baku. Kafetaria yang melibatkan peran masyarakat lokal sebagai penjual makanan dan minuman dilokasikan di tengah antara klaster biru dan klaster merah karena pada klaster merah sudah terdapat restoran Jambe Kembar. Tempat bersantai dapat ditambahkan di lokasi kafetaria sebagai tempat beristirahat. Selain itu, kafetaria ini juga dapat ditambahkan akses internet sebagai fasilitas tambahan untuk pengunjung.

\section{Analisis Tekno-Ekonomi Pabrik Pengolahan Nanas \\ Penentuan Kapasitas Produksi}

Sentra produksi nanas di Kabupaten Pemalang terletak di Kecamatan Belik. Kecamatan Belik berada pada posisi yang strategis karena berada di jalur selatan yang ramai dilewati oleh pengendara yang melakukan perjalanan dari Kabupaten Pemalang ke arah Purbalingga. Selain itu, Kecamatan Belik juga memiliki potensi wisata dengan adanya objek wisata
Curug Bengkawah, Telaga Silating, dan Jambe Kembar.

Produk olahan nanas di Kabupaten Pemalang dapat dikelompokkan menjadi tiga klaster, yaitu klaster buah segar, klaster minuman, dan klaster olahan. Buah segar didistribusikan oleh pengepul lokal yang kemudian didistribusikan ke pengepul antardaerah atau antarkota serta diteruskan ke pedagang pengecer. Klaster minuman diproduksi oleh UMKM Vitanas dan klaster olahan diproduksi oleh UMKM Citarasa, Nanas Madu Jaya, dan Sodong.

Buah segar memiliki pasar yang paling besar, yaitu sebanyak $90 \%$. Namun, buah segar memiliki kendala dalam masa simpan yang terbatas karena kandungan air yang tinggi sehingga mudah rusak. Buah segar merupakan produk yang perlu untuk dijual secara cepat sejak pemanenan (fast moving). Oleh karena itu, dalam penelitian ini pabrik dirancang untuk memproduksi buah potong segar yang ditargetkan untuk wisatawan yang berkunjung ke Kecamatan Belik. Buah potong segar dalam kemasan dapat dikonsumsi langsung oleh wisatawan dalam perjalanan atau dijadikan buah tangan untuk dapat segera dikonsumsi. Jumlah buah potong segar yang terjual diasumsikan sebanyak 2.191 kemasan per bulan. Jika setiap kemasan nanas potong segar berisi 320 gram, maka kapasitas produksi adalah $701 \mathrm{~kg}$ nanas potong segar per bulan. Limbah buah nanas dapat mencapai $60 \%$ dari keseluruhan buah nanas (Oktaviani et al., 2016). Jika limbah kulit dan mahkota sebanyak $60 \%$ dari buah nanas utuh, maka kebutuhan bahan baku buah nanas untuk memproduksi nanas potong segar untuk memenuhi target produksi adalah sebanyak 1.753 ton buah nanas per bulan.

Produk alternatif ditentukan dengan mempertimbangkan jenis produk yang menguasai pasar, yaitu buah segar. Keripik menjadi produk alternatif yang potensial untuk diproduksi karena keripik merupakan bentuk kering dari buah segar 
dengan tanpa atau sedikit penambahan aditif. Keripik memiliki kadar air yang sedikit sehingga dapat memiliki masa simpan yang lebih panjang dibandingkan buah segar. Oleh karena itu, pabrik dirancang untuk memproduksi keripik nanas dengan kapasitas bahan baku sejumlah $30 \%$ dari produksi buah nanas selama 3 bulan untuk produksi keripik selama setahun, yaitu sebanyak 1.900 ton per tahun atau 158 ton buah nanas per bulan.

Pengolahan nanas potong segar dan keripik melalui proses pengupasan terlebih dahulu karena keduanya dibuat dari daging buah nanas. Hal ini menunjukkan bahwa terdapat mahkota dan kulit buah nanas yang dapat menjadi limbah jika tidak dimanfaatkan. Padahal mahkota dan kulit nanas masih memiliki nilai gizi yang bermanfaat untuk dikonsumsi. Kandungan air yang masih tinggi menjadi pertimbangan untuk menjadikan jus/sari buah nanas sebagai alternatif produk yang diproduksi dengan memanfaatkan produk samping berupa mahkota dan kulit nanas. Oleh karena itu, pabrik dirancang untuk memproduksi jus/sari buah nanas dengan kapasitas bahan baku berupa produk samping mahkota dan kulit yang dihasilkan dari proses produksi nanas potong segar dan keripik, yaitu sebanyak 96 ton per bulan.

Nanas potong segar dipilih karena merupakan produk dengan nilai preferensi paling tinggi. Namun, nanas potong segar memiliki masa simpan yang terbatas. Oleh karena itu, dalam penelitian ini pasar nanas potong segar ditargetkan untuk wisatawan agrowisata. Alternatif produk lain dipilih berdasarkan kemiripan sifat dengan nanas potong segar namun memiliki masa simpan yang lebih lama. Alternatif produk yang dipilih adalah keripik nanas yang juga termasuk dalam produk yang cukup disukai. Kemudian, hasil produksi nanas potong segar dan keripik masih menghasilkan produk samping berupa cairan yang masih terkandung dalam kulit dan mahkota nanas. Oleh karena itu, jus/sari buah nanas dipilih sebagai alternatif produk selanjutnya untuk memanfaatkan produk samping. Dengan begitu, pabrik dirancang untuk memproduksi 3 produk berbasis nanas, yaitu nanas potong segar, keripik, dan jus/sari buah. Dalam hal ini, kapasitas total bahan baku buah nanas adalah sebanyak 160 ton per bulan.

\section{Pemilihan Teknologi Proses, Mesin, Dan Alat}

Teknologi proses yang digunakan untuk produksi buah potong segar adalah teknologi pengemasan untuk memperpanjang masa simpan buah potong segar. Buah segar dapat diperpanjang masa simpannya dengan teknologi pasca panen seperti pendinginan, pelapisan lilin, dan penyimpanan dengan udara terkendali. Pelapisan lilin biasanya digunakan untuk pada buah yang memiliki kulit. Pada penelitian ini, produk berupa buah potong segar sehingga pengemasan menggunakan kombinasi teknologi penyimpanan dengan udara terkendali dan pendinginan suhu. Penyimpanan dengan udara terkendali dapat dilakukan melalui modifikasi atmosfer (Modified Atmosphere Packaging - MAP), yaitu mengubah persentase kandungan udara yang bertujuan untuk menekan laju respirasi sehingga kesegaran buah terjaga lebih lama dan memperpanjang masa simpan buah segar. Kondisi MAP ini berbeda-beda untuk produk pangan yang bervariasi, bergantung pada banyak faktor seperti jenis produk, tujuan penggunaan, usia fisik, suhu penanganan, dan lama perlakuan (Yahia, 2009).

Penelitian-penelitian sebelumnya mengenai MAP buah nanas potong segar telah banyak dilakukan. Kualitas nanas potong segar dalam kemasan dapat terjaga dengan baik dengan penyimpanan suhu rendah selama 7 hari (Liu et al., 2007), 10 hari (Spanier et al., 1998), 14 hari (Budu et al., 2005; Montero-Calderon et al., 2008), dan 25 hari (Martinez-Ferrer et al., 2002). Rocculi et al. (2009) meneliti bahwa MAP dapat memperpanjang masa simpan nanas segar selama 3 - 4 hari. Kondisi terbaik untuk kemasan MAP nanas potong segar adalah pada campuran gas $4 \% \quad \mathrm{O}_{2}, 10 \% \quad \mathrm{CO}_{2}$, dan $86 \% \quad \mathrm{~N}_{2}$ (Martinez-Ferrer et al., 2002) yang memberikan masa simpan paling lama, yaitu hingga 25 hari pada suhu $5^{\circ} \mathrm{C}$.

Keripik yang baik adalah keripik yang memiliki tekstur yang renyah, tidak keras, tidak lembek, dan tidak mudah hancur. Kadar air yang tinggi menyebabkan tekstur keripik menjadi kurang renyah. Teknologi pembuatan keripik yang umum digunakan adalah teknik penggorengan dan pengeringan. Pengeringan keripik dapat dilakukan sinar matahari dan oven atau cabinet dryer. Namun, pengeringan dengan cara ini menghasilkan keripik dengan permukaan keriput, kurang porous, densitas tinggi, warna lebih gelap, dan berkurangnya nilai gizi. Pada teknik penggorengan, minyak goreng digunakan untuk menghasilkan makanan yang gurih dan renyah. Pada saat proses penggorengan, terjadi perpindahan panas dan massa dengan minyak sebagai media penghantar panas (Suyitno, 1991).

Teknik penggorengan yang paling umum adalah penggorengan manual atau deep frying, yaitu penggorengan menggunakan banyak minyak sehingga makanan benar-benar terendam pada tekanan atmosfer terbuka. Suhu penggorengan biasanya dilakukan pada $150-190^{\circ} \mathrm{C}$, bergantung pada kualitas minyak goreng. Suhu yang cukup tinggi ini dapat merusak nilai gizi tertentu yang terkandung dalam makanan. Masalah tersebut dapat diatasi dengan teknik penggorengan hampa, yaitu penggorengan yang dilakukan dalam kondisi vakum pada tekanan rendah di bawah tekanan atmosfer dan suhu rendah di bawah suhu penggorengan minyak pada tekanan atmosfer. Pada teknik penggorengan hampa berlaku Hukum Gay Lussac. Pada ruang hampa atau volume tetap, semakin tinggi tekanan, maka semakin tinggi pula suhu di ruang tersebut. Sebaliknya, semakin rendah tekanan, maka semakin rendah suhu pada ruang tersebut. Hal ini 
menyebabkan penggorengan dapat dilakukan pada suhu rendah. Dengan begitu, dapat dihasilkan produk dengan kualitas yang lebih baik dibandingkan penggorengan biasa pada tekanan atmosfer.

Mariscal dan Bouchon (2008) menemukan bahwa kandungan minyak lebih rendah pada keripik dengan menggunakan penggorengan vakum. Da Silva dan Moreira (2008) juga menemukan bahwa teknologi penggorengan vakum menghasilkan keripik buah dan sayur yang berkualitas tinggi. Secara umum, hasil dari penggorengan vakum lebih mempertahankan warna dan rasa yang alami karena kurang teroksidasi dan suhu penggorengan yang lebih rendah. Hal ini ditunjukkan dengan dengan kandungan minyak yang lebih rendah pada keripik dan kandungan karotenoid yang lebih tinggi dibandingkan penggorengan konvensional pada tekanan atmosfer. Selain itu, keripik dengan penggorengan vakum juga lebih disukai panelis dari warna, tekstur, rasa dan kualitas secara keseluruhan. Sebagian besar produk mempertahankan warna aslinya ketika digoreng vakum. Penggorengan tradisional menunjukkan penggelapan dan panas yang berlebihan.

Granda et al. (2004) menemukan bahwa kadar akrilamida lebih tinggi pada penggorengan tradisional dibandingkan dengan penggorengan vakum. Penggorengan vakum dapat menurunkan pembentukan akrilamida hingga 94\%. Crosa et al. (2014) menemukan bahwa penggorengan vakum menghasilkan penurunan yang signifikan terhadap laju reaksi deteriorasi dalam minyak.

Penggorengan vakum dapat digunakan untuk memproduksi keripik nanas sehat yang dapat menjaga kualitas warna dan nutrisi secara parsial dan memiliki kapasitas antioksidan hidrofilik yang tinggi (PerezTinoco et al., 2008). Keripik hasil penggorengan vakum disukai karena memiliki tekstur yang renyah dan memiliki rasa dan aroma seperti buah aslinya (Sofyan, 2004). Kondisi penggorengan vakum dirancang pada suhu $112^{\circ} \mathrm{C}$ selama 6,9 menit dengan tekanan $24 \mathrm{kPa}$ (Perez-Tinoco et al., 2008). Keripik yang dihasilkan memiliki kadar air berkisar 4\% dan kadar minyak berkisar $20 \%$ yang memenuhi baku mutu SNI 01-4304-1996.

Teknologi yang dipilih dalam penelitian ini untuk pengemasan buah potong segar adalah MAP yang disimpan pada suhu dingin $\left(5^{\circ} \mathrm{C}\right)$, sedangkan keripik nanas menggunakan teknologi pengolahan penggorengan vakum. Pemilihan mesin dan alat ditentukan berdasarkan tahapan proses dan kapasitas mesin dan alat yang dibutuhkan. Kebutuhan mesin dan peralatan proses terdiri dari mesin pengupas nanas, mesin pencuci buah nanas yang telah dikupas, mesin pemotong nanas, mesin penggorengan vakum, tangki minyak, pompa minyak, mesin penghancur dan penekan, mesin pencampuran, mesin pengemasan, dan mesin perekat kemasan (sealer). Kebutuhan utilitas dan penanganan bahan terdiri dari generator, tangki air, pompa air, timbangan, forklift, palet plastik, hand pallet, ruang pendingin, boiler, dan instalasi pengolahan air (sand filter dan ion exchanger). Diagram alir proses ditunjukkan pada Gambar 4 yang menunjukkan aliran proses, aliran air, aliran air pencucian, aliran steam, aliran limbah, dan aliran gas. Diagram alir proses dibuat dengan menggunakan perangkat lunak Edraw Max 9.2.

\section{Perhitungan Neraca Massa}

Perhitungan neraca massa diperlukan untuk mengetahui jumlah nilai tambah yang dihasilkan. Diagram alir dan neraca massa ditunjukkan pada Gambar 5. Pada tahap awal, daging nanas dipisahkan dari mahkota dan kulitnya. Pada tahap selanjutnya, daging nanas dipotong sehingga dihasilkan produk nanas potong segar. Nanas potong segar diproses lebih lanjut melalui penggorengan vakum untuk menghasilkan keripik.

Produk samping berupa mahkota dan kulit nanas diproses lebih lanjut melalui proses penghancuran dan penekanan untuk menghasilkan sari buah. Limbah nanas masih mengandung air sebanyak 60\% (Gil et al., 2017). Sari limbah ini dicampurkan bahan-bahan tambahan untuk menghasilkan jus/sari buah siap minum. Dalam proses pencampuran, sari buah nanas ditambahkan dengan bahan-bahan aditif. Produk yang dihasilkan per bulan dengan kapasitas bahan baku nanas sebanyak 160 ton adalah $701 \mathrm{~kg}$ nanas potong segar, 13 ton keripik, dan 57,78 ton jus/sari buah nanas

\section{Modal Investasi}

Model investasi terdiri dari investasi langsung dan tidak langsung. Komponen modal investasi langsung terdiri dari biaya tanah, biaya bangunan dan sarana, harga peralatan terpasang, instrumentasi dan alat kontrol, biaya perpipaan, biaya instalasi listrik, biaya insulasi, biaya inventaris kantor, dan sarana transportasi. Rincian modal investasi langsung ditunjukkan pada Tabel 3.

Komponen modal investasi tidak langsung terdiri dari biaya perizinan, engineering dan supervisi, biaya kontraktor, biaya tak terduga, dan biaya konstruksi. Rincian modal investasi tidak langsung ditunjukkan pada Tabel 4. Total modal investasi langsung dan tidak langsung adalah sebesar Rp12.287.857.290 


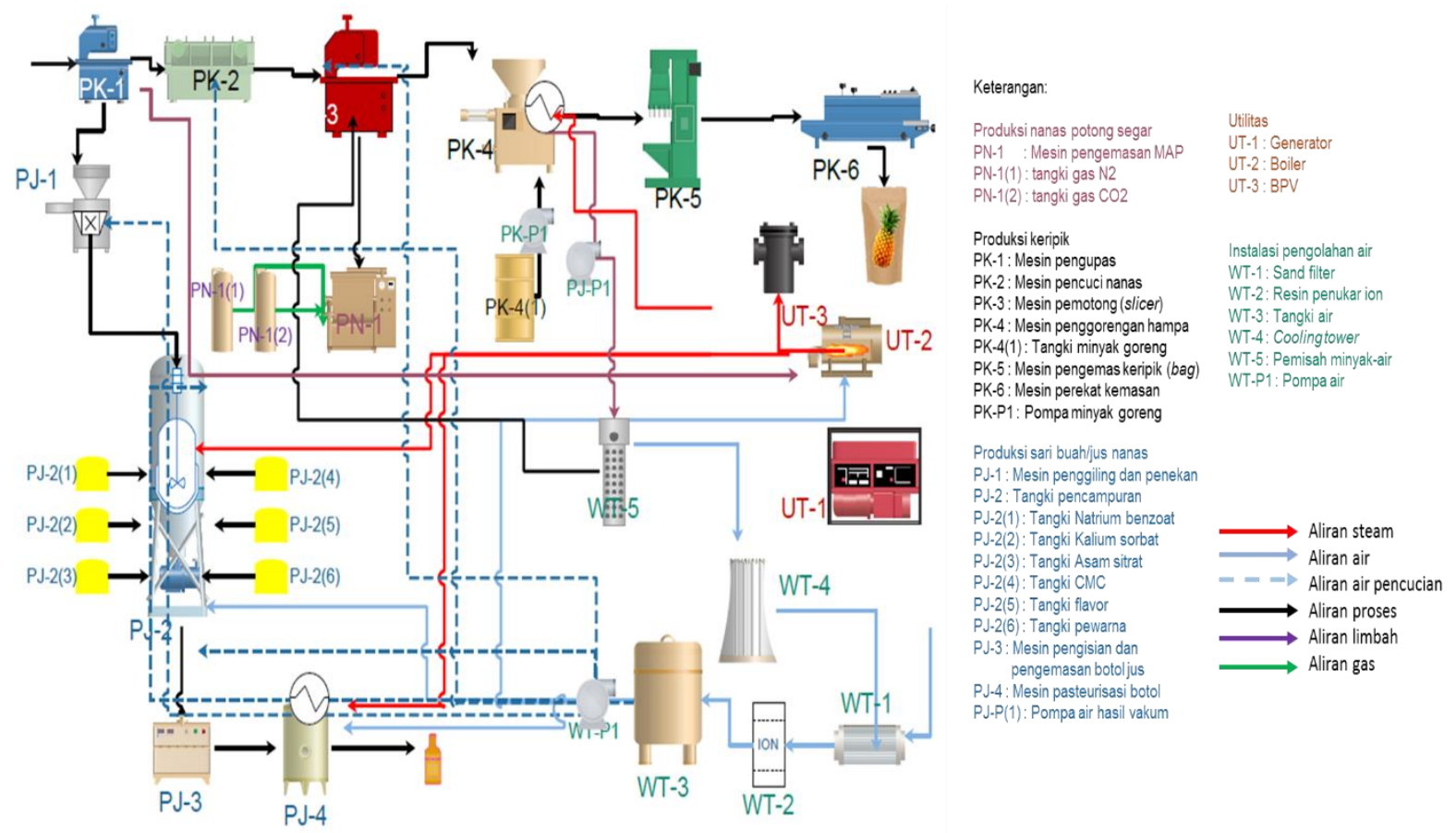

Gambar 4. Diagram aliran proses produksi pabrik pengolahan nanas

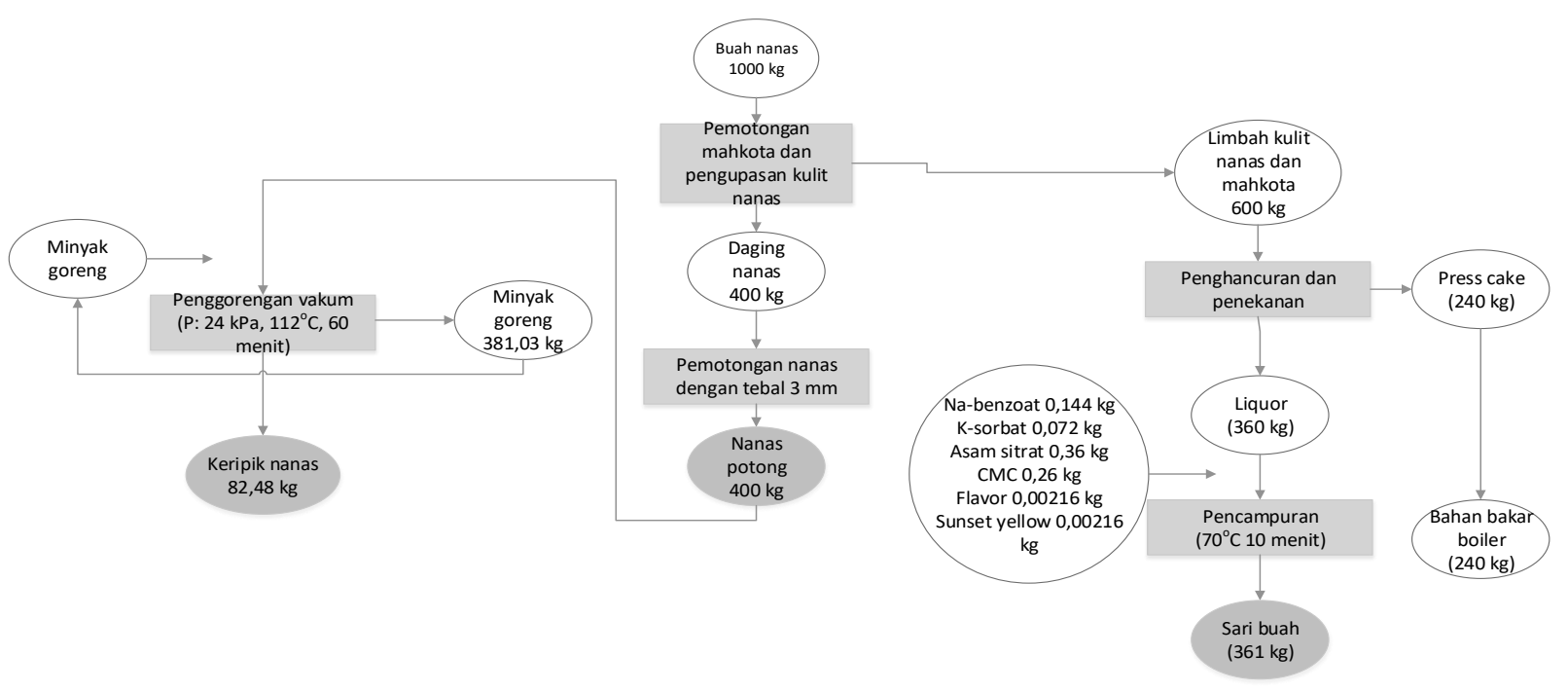

Gambar 5. Diagram alir dan neraca massa

$\underline{\text { Tabel 3. Modal investasi langsung }}$

\begin{tabular}{clr}
\hline No & Komponen & Harga total (Rp) \\
\hline 1 & Biaya tanah & 401.367 .000 \\
2 & Biaya bangunan dan sarana & 1.319 .200 .000 \\
3 & Harga peralatan terpasang (HPT) & 4.100 .521 .000 \\
4 & Instrumentasi dan alat kontrol (26\% HPT) & 1.066 .135 .460 \\
5 & Biaya perpipaan (7\% HPT) & 287.036 .470 \\
6 & Biaya instalasi listrik (10\% HPT) & 410.052 .100 \\
7 & Biaya insulasi (8\% HPT alat membutuhkan panas) & 192.972 .160 \\
8 & Biaya inventaris kantor (1\% HPT) & 41.005 .210 \\
9 & Sarana transportasi (10\% HPT) & 410.052 .100 \\
\hline Jumlah investasi langsung & 8.228 .341 .500 \\
\hline
\end{tabular}


Tabel 6. Analisis sensitivitas terhadap kenaikan harga bahan baku

\begin{tabular}{cccc}
\hline \multirow{2}{*}{ Kriteria } & Basis & $\mathbf{1 7 \%}$ & Nilai \\
& Rp18.506.493.138 & Rp10.856.621.198 & Rp10.406.628.730 \\
\hline NPV & $19,03 \%$ & $11,42 \%$ & $10,96 \%$ \\
IRR & 2,51 & 1,88 & 1,85 \\
Net B/C & 4,26 & 6,88 & 6,76 \\
PBP (tahun) & &
\end{tabular}

Tabel 4. Modal investasi tidak langsung

\begin{tabular}{clc}
\hline No & \multicolumn{1}{c}{ Komponen } & \multicolumn{1}{c}{$\begin{array}{c}\text { Harga total } \\
(\mathbf{R p})\end{array}$} \\
\hline 1 & $\begin{array}{l}\text { Biaya perizinan (4\% HPT) } \\
\text { Engineering dan supervisi } \\
2\end{array}$ & $\begin{array}{l}164.020 .840 \\
(32 \% \text { HPT) }\end{array}$ \\
3 & $\begin{array}{l}\text { Biaya kontraktor (19\% } \\
\text { HPT) }\end{array}$ & 779.098 .990 \\
4 & $\begin{array}{l}\text { Biaya tak terduga (10\% } \\
\text { HPT) }\end{array}$ & 410.052 .100 \\
5 & $\begin{array}{l}\text { Biaya konstruksi (34\% } \\
\text { HPT) }\end{array}$ & 1.394 .177 .140 \\
\hline Jumlah investasi tidak langsung & 4.059 .515 .790 \\
\hline
\end{tabular}

\section{Modal Kerja}

Modal kerja disiapkan untuk pabrik beroperasi selama 3 bulan. Komponen modal kerja ini meliputi biaya bahan baku, biaya pemasaran, biaya administrasi, gaji pegawai, dan pajak. Jumlah modal kerja untuk 3 bulan operasi sebesar Rp5.292.243.387 (Tabel 5).

Tabel 5. Modal kerja (3 bulan)

\begin{tabular}{clr}
\hline No & Komponen & Harga total (Rp) \\
\hline 1 & Biaya bahan baku & 3.904 .108 .579 \\
2 & Biaya pemasaran & 266.717 .425 \\
3 & Biaya administrasi & 53.343 .485 \\
4 & Gaji pegawai & 104.370 .000 \\
5 & Pajak & 963.703 .899 \\
\hline \multicolumn{2}{c}{ Total modal kerja } \\
\hline
\end{tabular}

Kriteria kelayakan usaha dilihat dari nilai NPV, IRR, PBP, Net B/C, dan BEP. Hasil perhitungan menunjukkan NPV Rp18.506.493.138; IRR 19,03\%; PBP 4,26 tahun; Net B/C 2,51; dan BEP $41,47 \%$. Proyek dinyatakan layak untuk dijalankan dikarenakan nilai NPV positif, IRR lebih besar dari discount rate, dan Net B/C lebih besar dari 1. Nilai NPV menunjukkan positif menunjukkan bahwa proyek ini menguntungkan. IRR lebih besar dari discount rate menunjukkan bahwa investasi pada proyek ini lebih menguntungkan dibandingkan melakukan deposito di bank. Net B/C sebesar 2,51 bermakna pada setiap investasi sejumlah Rp1 akan memperoleh manfaat sebesar Rp2,51. Nilai Net B/C yang cukup besar ini dapat menjadi daya tarik bagi investor untuk melakukan investasi.

Hasil analisis sensitivitas menunjukkan bahwa pabrik menjadi tidak layak ketika terjadi kenaikan harga bahan baku sebesar 17 - 18\% (Tabel 6) atau penurunan harga jual sebesar $7-8 \%$ (Tabel 7). Kelayakan pabrik ini cukup sensitif terhadap harga bahan baku dan harga jual produk. Sensitivitas ini dipengaruhi oleh pajak yang memiliki porsi yang sangat besar terhadap perolehan laba bersih. Porsi sangat besar ini menyebabkan kelayakan pabrik menjadi sensitif. Kondisi ini dapat mengurangi minat investor untuk melakukan investasi. Oleh karena itu, dibutuhkan dukungan dari pemerintah berupa pengurangan atau subsidi pajak.

Menurut PMK No.197/PMK.03/2013, PPN diwajibkan kepada Pengusaha Kena Pajak (PKP), yaitu pengusaha yang memiliki transaksi penjualan melebihi Rp4,8 Miliar per tahun. Nilai PPN yang diambil sebanyak $10 \%$ dari penghasilkan bruto memberi pengaruh yang sangat besar karena tidak mempertimbangkan persentase keuntungan pabrik. Proses pembuatan keripik telah mengalami penyusutan pada proses pengeringan. Besarnya nilai PPN akan lebih baik jika menyesuaikan dengan jenis industri. Menurut Undang-Undang No. 42 tahun 2009 tentang Pajak pertambahan nilai barang dan jasa dan pajak penjualan atas barang mewah Pasal 7 ayat 1 , tarif PPN dapat berubah menjadi paling rendah 5\% dan paling tinggi 15\%. Dukungan berupa pengurangan pajak ini dapat meningkatkan kelayakan pabrik sehingga lebih menguntungkan dan meningkatkan minat investor. Dengan begitu, potensi pendirian pabrik lebih besar dan pemerintah pun mendapat pemasukan dari pajak yang dikeluarkan oleh pelaku.

\section{KESIMPULAN DAN SARAN}

\section{Kesimpulan}

Hasil penelitian mengenai pengembangan agroindustri terintegrasi di kawasan agrowisata berbasis nanas di Kabupaten Pemalang menghasilkan simpulan bahwa fasilitas kawasan sesuai preferensi pengunjung terdiri dari kunjungan pabrik pengolahan nanas, tempat bersantai, tempat bermain anak, kafetaria atau tempat makan, tempat berfoto, toko cindera mata, susur kebun nanas, dan akses internet. 
Tabel 7. Analisis sensitivitas terhadap penurunan harga jual

\begin{tabular}{|c|c|c|c|}
\hline \multirow{2}{*}{ Kriteria } & \multicolumn{3}{|c|}{ Nilai } \\
\hline & Basis & $7 \%$ & $8 \%$ \\
\hline NPV & Rp18.506.493.138 & Rp10.726.105.225 & Rp9.612.906.538 \\
\hline IRR & $19,03 \%$ & $11,32 \%$ & $10,19 \%$ \\
\hline Net B/C & 2,51 & 1,87 & 1,78 \\
\hline PBP (tahun) & 4,26 & 6,88 & 6,58 \\
\hline
\end{tabular}

Produk nanas yang lebih disukai responden adalah buah segar, pai nanas, jeli, manisan, selai, keripik, jus atau sari buah, nata de pina, permen, sirup, dan stik nanas. Lokasi strategis kawasan agrowisata terintegrasi dengan agroindustri nanas di Kabupaten Pemalang adalah Kecamatan Belik sekaligus sebagai sentra produksi nanas madu Pemalang. Pabrik pengolahan produk berbasis nanas beroperasi pada kapasitas bahan baku 160 ton per bulan untuk memproduksi nanas potong segar, keripik, dan jus/sari buah masing-masing sebanyak $701 \mathrm{~kg}, 13$ ton, dan 57,78 ton per bulan. Pabrik pengolahan layak didirikan dengan modal investasi Rp12.287.857.290 dan modal kerja Rp5.292.243.387 untuk menghasilkan NPV Rp18.506.493.138; IRR 19,03\%; PBP 4,26 year; Net B/C 2,51; dan BEP $41,47 \%$.

\section{Saran}

Pengembangan agroindustri terintegrasi di kawasan agrowisata nanas perlu dilakukan dengan dukungan kebijakan pemerintah daerah terkait infrastruktur pendukung dan anggaran melalui skema kerjasama pemerintah swasta. Penelitian lanjutan yang dapat dilakukan adalah pengembangan produk olahan berdasarkan kelayakan tekno-ekonominya, perancangan pabrik meliputi rancangan instalasi pengolahan limbah cair, dan analisis kelembagaan.

\section{DAFTAR PUSTAKA}

[Bappeda Pemalang] Badan Perencanaan Pembangunan Daerah Kabupaten Pemalang. 2016. Laporan Akhir Kajian Pengembangan Budidaya Nanas di Kabupaten Pemalang. Pemalang(ID): Bappeda.

[BPS Pemalang] Badan Pusat Statistik Kabupaten Pemalang. 2018. Pemalang Dalam Angka. Pemalang(ID): Percetakan Taman Asri.

Budu AS dan Joyce DC. 2005. Effect of modified atmosphere packaging on the quality of minimally processed pineapple cv. 'Smooth Cayenne' fruit. Journal Hort Sci Biotech. 80(2): 193-198.

Cohen L, Manion L, dan Morrison K. 2007. Research Methods in Education. Oxon(UK): Routledge. 101.
Crosa MJ, Skerl V, Cadenazzi M, Olazabal L, Silvia R, Suburu G, Torres M. 2014. Changes produced in oils during vacuum and traditional frying of potato chips. Journal Food Chem. 146: 603-607.

Da Silva PF dan Moreira RG. 2008. Vacuum frying of high-quality fruit and vegetable-based snacks. JFST. 41: 1758-1767.

Djamhari C. 2004. Orientasi Pengembangan Agroindustri Skala Kecil Dan Menengah; Rangkuman Pemikiran. Infokop. No. 25(Tahun XX): 121-32.

Djamudin, Fauzi AM, Arifin HS, Sukardi. 2012. Studi pengembangan agroindustri dan agrowisata terpadu di daerah aliran sungai (DAS) Kali Bekasi Kabupaten Bogor. Jurnal Teknologi Industri Pertanian. 22(3) 151-163.

Fakhrurrazi. 2018. Analisis pengembangan agrowisata berbasis agroindustri kakao di Kabupaten Pidie Jaya Provinsi Aceh [tesis]. Bogor(ID): IPB University.

Gil LS dan Maupoey PF. 2017. An integrated approach for pineapple waste valorisation. Bioetahnol production and bromelain extraction from pineapple residues. Journal Cleaner Production. 172: 1224-1231.

Granda C, Moreira RG, Tichy SE. Reduction of acrylamide formation in potato chips by lowtemperature vacuum frying. JFS. 69(8): E405E411.

Herman AS. 2007. Model agroindustri bawang merah Brebes. JRI. 1(1): 45-58.

Ikasari DM, Nurika I, Suprayogi, Meidiana C, Damayanti R. 2018. Upaya pengembangan desa agrowisata melalui penguatan agroindustri terpadu produk unggulan daerah (buah naga dan jeruk siam) di Desa Temurejo, Banyuwangi. Prosiding Semnas PPM 2018. 1(1): 1397-1405.

Joen D. 2016. Analisis potensi dan strategi penentuan kawasan agroindustri untuk dikembangkan di Kabupaten Lampung Selatan [tesis]. Bandar Lampung(ID): Universitas Lampung.

Kasmir J. 2004. Studi Kelayakan Bisnis. Jakarta: Kencana Prenada Media. 368 p.

Liu C-L, Hsu C-K, Hsu M-M. 2007. Improving the quality of fresh-cut pineapples with ascorbic acid/sucrose pretreatment and Modified 
Atmosphere Packaging. Packag. Technol. Sci. 20:337-343.

Marimin dan Maghfiroh N. 2010. Aplikasi Teknik Pengambilan Keputusan Dalam Manajemen Rantai Pasok. Bogor(ID): PT Penerbit IPB Press.

Mariscal M dan Bouchon P. 2008. Comparison between atmospheric and vacuum frying of apple slices. Journal Food Chem. 107: 15611569.

Martinez-Ferrer M, Harper C, Perez-Munoz F, Chaparro M. 2002. Modified atmosphere packaging of minimally processed mango and pineapple fruits. Journal Food Eng Phisic Prop. 67(9): 3365-3371.

Montero-Calderon M, Rojas-Grau MA, MartinBelloso O. 2008. Effect of packaging conditions on quality and shelf-life of freshcut pineapple (Ananas comosus). Journal Postharv Bio. 50(2-3): 182-189.

Oktaviani R, Rahayu K, dan Suhartatik N. 2016. Pemanfaatan limbah nanas (Ananas comocus L. Merr) pada pembuatan kecap ikan lele (Clarias sp) dengan variasi lama fermentasi. Jurnal Teknologi Industri Pangan. 1(2): 134 143.

Perez-Tinoco MR, Perez A, Salgado-Cervantes M, Reynes M, Vaillant F. 2008. Effect of vacuum frying on main physicochemical and nutritional quality parameters of pineapple chips. Journal Science Food Agric. 88: 945953.

Rocculi P, Cocci E, Santina R, Giampiero S, Rosa MD. 2009. Effect of 1-MCP treatment and $\mathrm{N} 2 \mathrm{O}$ MAP on physiological and quality changes of fresh-cut pineapple. Journal Postharv Bio. 51: 371-377.
Rosyanta PMC, Satriawan IK, dan Yoga IWGS. 2018. Strategi pengembangan usaha agroindustri kopi luwak pada Satria Agrowisata di Kabupaten Gianyar. Jurnal Rek Manaj Agro. 6(4): 269-277.

Sofyan I. 2004. Mempelajari pengaruh ketebalan irisan dan suhu penggorengan secara vakum terhadap karakteristik keripik melon. Infomatek. 6(3): 161-180.

Spanier AM, Flores M, James C, Lasater J, Lloyd S, Miller JA. 1998. Fresh-cut pineapple (Ananas sp.) flavor. Effect of storage. Food flavors: formation, analysis and packaging influences. Proceedings of the 9th International Flavor Conference The George Charalambous Memorial Symposium. 331-343.

Supriatna A, Rambitan UN, Sumangat D, Nurdjannah N. 2004. Analisis sistem perencanaan model pengembangan agroindustri minyak daun cengkeh: Studi kasus di Sulawesi Utara. Bullenti Littro. 15(1): 1-18.

Suryani T. 2013. Analisis peran sektor ekonomi terhadap pertumbuhan ekonomi Kabupaten Pemalang (Analisis tabel input output Kabupaten Pemalang tahun 2010). Eco Dev Anal Journal 2(1).

Stone H dan Sidel JL. 1985. Sensory Evaluation Practices. London(UK): Academic Press. 230-236.

Suyitno. 1991. Deep Fat Fryer. Yogyakarta(ID): PAU Pangan dan Gizi Universitas Gadjah Mada.

Yahia EM. 2009. Modified and controlled atmospheres for the storage, transportation, and packaging of horticultural commodities. Boca Raton(FL): CRC Press 